Independent Journal of Management \& Production (IJM\&P) ISSN: 2236-269X DOI: 10.14807/ijmp.v3i2.42 v. 3, n. 2, July - December 2012

\title{
INSIGHT INTO INTRA-ORGANIZATIONAL LEARNING AND KNOWLEDGE MANAGEMENT
}

\author{
Mohammad Rizwan Junaid \\ Pakistan Institute of Management, Ministry of Industries, Govt. of Pakistan \\ E-mail: falsafi_28@yahoo.com
}

Submission: 06/10/2012

Accept: 08/11/2012

\begin{abstract}
Intra-Organizational learning and knowledge management has increasingly becomes a subject of extreme importance as organizations round the globe are working on increasing their productive efficiency through continuously working on their human and intellectual capital. The core focus of this paper is to take into account the core issues that hamper and accelerate the process of knowledge generation, codification, retention and transfer within an organization. The role of social networking, individual relationships, experiencing, multi-tasking are the focal areas that have been taken into consideration while studying the knowledge management process at different levels within an organization.
\end{abstract}

Key-words: Organizational Learning, Knowledge Management, Generation, Codification, Retention, Transfer

\section{Introduction}

It is evident that an organization keeps on learning and the pace is settled in the perspective of two notions change and plans, whenever there is a technology shift or if an organization plans for diversification (Senge, 1990) to ensure an edge in such a competitive market place. Individual learning and organizational learning are two different spheres, the culture advocates the possibility of organizational learning. The intrinsic concept of organizational learning has been a concrete part of the management literature but it gained the wide span recognition in the second half of 1990s (EasterbySmith, 1999); learning as a faculty belong to an individual mind, the process of thinking and remebering (Prange, 1999) but when it becomes a group activity with a clear sense 
Independent Journal of Management \& Production (IJM\&P) ISSN: 2236-269X DOI: 10.14807/ijmp.v3i2.42

v. 3, n. 2, July - December 2012

of objectivity, then we call it organizaitonal. This collective approach of learning , the connection of individual and organizational learning is based upon a corelation between the incomplete input from a member which is combined among memebers and get a complete over view (Argyris, 1996), the concept of collective wisdom.

Intra-organizational learning is purely an objective aspect of learning as it is initiated because of and carried on because of and this because of as new knowledge is deposited in due repositores with an aim to retain it for quiet sometime (Argote, 2000). Eventhough learning seems objective when it comes to Organization but it is not necessary that every learning is fruitful or to be used, the pro-active learning leads to outcome that often are not accepted or appreciated by the surroundings in which an organization operates, contrary to adaptive learning that is reactionary mode of learning to accommodate internal and external environmental changes while advanced or proactive learning is higher or strategic/generative learning (Argyris C. \& Schön D, 1978; Fiol,1985; Dodgson, 1991). Experimental learning, is deducing meaning from direct experience (Itin, 1999) although it produces results in the shorter run but fails in the longer spell as repitition of the same does not allow to look into the changes that had to be incorporated over time as the concept of change accomodation describes. Organization and it subunits [departments] share/transfer knowledge to one another and collective learning takes place, often through experince and sometimes in speculative mode rather immitating the same act to produce desired results, for instance a new tool is brought by one department and being used, at the same time by involving people from other departments the knowledge of the tool can be transferred, learning can be made easy by involving people with expert on a porject or assignment. Overall, it can be said that organizational learning is a process that undertakes all the departments, division and stations across organization and in fact it is like making all members learn and having itself transformed all the times (Mike Pedler, 1991).

The core sub-processes relate to roganizational learning are, creating, codifying, retaining and disseminating knowledge across organization in order to have a uniform flow of knowledge, keeping every one on board.Creating knowledge refers to the interaction of group of employees within organization who are involved in a new task 
Independent Journal of Management \& Production (IJM\&P) ISSN: 2236-269X DOI: 10.14807/ijmp.v3i2.42

v. 3, n. 2, July - December 2012

and gain new dimensions of knowledge, once the task is accomplished and they may use this knwledge to create value for the organization, in another way the combination of individual knowledge may pave the way for a new knowledge sphere which adds productive value for the organization. The core challenge being faced by a firm is to generate knowledge from the source and make it available where it is required (Ruggles, 1998; Fahey, 1998); Knowledge codification is to transform individual and group knowledge in easy, understandable and usable form and make it something of use for every one involved in organizational functions and processes as documenting the knowledge. Retaining knowledge is to link knowledge repositories in an objective manner as Knowledge is influenced by external influences as well as internal influences; knowledge may become a competitive advantage, but may also contribute to inertia. If a company is bathed in the true spirit of learning (Senge, 1994), it will develop structures and processes which create a balanced and complementary effort towards combining knowledge acquisition from inside and outside of the firm. Disseminating knowledge with in organization incorporates three broader ways as awareness, understanding and action (Serrat, 2009) and these are combined to utlize knowledge in achieving goal. Organizational learning is purely objective and it is fairly stimulated by knowledge obsolense or the performance of specific departments (technological automation, product diversification).

Measuring learning efficiency of an organization coupled with assessment of chages in knowledge is an intricate task; as tacit knowledge is difficult to be documented, difficult to be verbalized (Berry, 1984) and most of what is documented is related to experience, further more the active knowledge repositories within an orgnization are humans and non-humans, these non human repositories where captured knowledge is retained and stored must be organized in an accesible manner as the focus of Organizaitonal learning is based upon building organizationl capability (Armstrong,2000; Pettigrew,1991). These non-human repositories are (Bacdayan, 1994) Organizational routines-multi-actor, interlocking, reciprocally-triggered sequences of actions - a major source of the reliability and speed of organizational performance. 
Independent Journal of Management \& Production (IJM\&P) ISSN: 2236-269X DOI: 10.14807/ijmp.v3i2.42

v. 3, n. 2, July - December 2012

The counter phase of measuring learning within organization is to focus on individual and department's performance linked with experience, but it is even difficult to relate measurement of learning with experience as there are scores of factors that affect individual performance, as psychological and social (Koppes, 2007; O'Connor, 2006; Stringer, 2007; Mitchell, 2003; W.C. Borman, 2003; Locke, 1990; Latham, 2005; Kozlowski, 2003; Salas \& Stagl, 2004; Van Vianen, 2001; Anderson, Ones, \& Sinangil, 2002; Schmidt, 1998; Leonard, 1998; Pfeffer, 1999) organizational context and information technology (IT) applications (Soonhee Kim, 2010; Robertson, 2008) and other work place related factors as mentioned by campbell (1990) that several performance parameters that may have important implications for the job performance setting and should be investigated by industrial and organizational psychologists. A variation in human experience is multi-dimensional but the peculiarity is that, there has always been a positive relationship between diversified human experience and organizational performance. The sole aim is to focus upon intra-organizational learning process that appears in two distinct spheres as inside a department,sub-unit, strategic business unit or section and between/among departments, divisions, sections, sub-units etc,.

\section{Review of related literature}

The Organizational learning process actively takes place in two different dimensions as sequential \{knowledge creation, codification, retention, dissemination\} and procedural that lies in basic networks and their combination that occurs due to change in working knowledge and experiences that undertake exploitation and exploration activities (Mary M. Crossan, 1999).The operational side of the organization runs through the combination of Man-Machine-Task (production, quality control, stores, packing,maintenanace etc) while the functional side of the organization runs through the combination of Member-Task. The core difference that is to be considered between these two orgnizational spheres is that, in operations the dominanace is of machine, so the knowledge repository is non-human i.e. [machines], the importance of Man is evenly parallel to machine in a facilitating condition (Hartness, 1912; Wilson, 1995; Richard Chase, 2001) but the output is based upon machine knowledge and performance. While 
Independent Journal of Management \& Production (IJM\&P) ISSN: 2236-269X DOI: 10.14807/ijmp.v3i2.42

v. 3, n. 2, July - December 2012

in functions the focal knowledge is in humans as the output is based upon human and machine is in facilitating condition. It is difficult to frame the learning sphere of any organization with a vital theoratical construct, since that, an organization runs through the combination of functions and operations and the knowledge repositories of these two factions run along side. The most important and key element is the human factor (Drucker, 2002; Davenport, 1998; Sveiby, 1997) in acquiring and maintaining functional (member-task) and operational (member-tool-task) knowledges.

In member-task performance, the best men (employees) are selected for the job and their interaction with in the group and other allied groups increases organizational performance and interactiveness as group based \{project based\} (Evensen, 2000); learning has been named as problem based learning as during the task reflecting and responding to problem (Barrows, 1988) intiates a new mode of learning withiin the group and organization as well.

In member-tool-task a provision of new knowledge seems dependent upon the technology being used by the performers. It brings a sense of interaction among people, it is quiet possible that the standings and behavior of an employee is different in his group as compared to what he exposes in organization. The organizational layers of behavior and interaction are different from departmental layers and tares. The core is forming networks within departments, among departements, within organization and among organizations. According to Miles and Snow (Miles, Snow, 1986), networks considered as forms of flexible work - also encourage cooperation because of the informality which characterizes them. Informality of interpersonal relationship brings people to share more knowledge in the explicit form, which is usually hard to make explicit (Nonaka, Takeuchi, 1995). It is noted that the chnages in the social positioning of a member in a group, in a department and in an organization also affects the learning process within organization. Organization, as a whole takes into account the collective goal and the residing knowledge at this level is in its accumulated form, while at departmental and individual level the shape of knowledge is different and it appears in more of its individual or personal form. 
Independent Journal of Management \& Production (IJM\&P) ISSN: 2236-269X DOI: 10.14807/ijmp.v3i2.42

v. 3, n. 2, July - December 2012

There are lots of studies available in Intra-organizational learning but our main aim is to look into those sub-processes that are changed in accordance with the main processes, because the new generation of knowledge management focuses upon down the line changes that are presumeabily the outcome of Top Management's involvement in the whole process. The net work of knowledge management is getting wider and bigger and loops are widen enough to envelope whole organization into their fold.

\section{Knowledge Creation}

It is evident that every organization keeps its own pace and set of knowledge and this pace and set of knowledge is influenced by the people who interact with each other, individual characteristics of organizational members do effect the process of knowledge creation as it is a balance between knowledge and knowing (Cook, 1999) and a creative dance between knowledge and knowing. The issue of diversity is even critical at this stage as an organizational knowledge is to undertake internal and external factors at the same time and in fact the intrinsic understanding of this area needs extensive focus (Ashby, 1956; E. Rullani, 1990) since that, as long as market is rigid and conservative the prevailing knowledge base is enough to cater the requirements of the corresponding market but the moment market goes complex and segmented; product diversification becomes a critical success factor that needs creation of new knowledge.

The role of diversity in intra-organizational knowledge creation sustains the core value (March, 1991) and knowledge diversity is proposed as the very source of organization innovation and adaptability (Molani, 2003). It is evident that by every passing day organizations seem more dependent on diverse groups; especialy in product innovation, problem solving and efficiency increment (Dahlin, 2005) and prevailing scenario advocates the possibility of better consequences if organization bring experts to solve complex problems (Cagan, 2002). The challenge being faced by organizations round the globe is to manage increasingly diverse workforce (Offerman, 1990; Lyness, 1997) and in this very regard different studies have been undertaken to understand the control of knowledge and having it communicated in a cost effective mennaer to people from different backgrounds (Riordan, 2001; Williams, 1998; Milliken, 1996). 
Independent Journal of Management \& Production (IJM\&P) ISSN: 2236-269X DOI: 10.14807/ijmp.v3i2.42

v. 3, n. 2, July - December 2012

The issue of demographic diversity has it clarified that hetrogenous groups are more supportive (Cox, 1991) and appear innovative (Jehn, 1999; O'Reilly, 1997) and their role in complex problem solving is more effective (Kirchmeyer, 1992). Organizational groupings are always task orineted and it has been observed that hetrogeneous groups appear more creative and functional as compared to homogeneous groups and the level of one another's acceptance is higher in these groups. Diversly educated and composed Top Management teams give corporation an edge (Pfau, 2005) and they are more active and advanced as compared to their homogeneous counterparts (Jackson, 1989; Hambrick DC, 1996; Daniel Henneke, 2007). In the very case of new product development and product innovation projects, multifunctional project teams speed up the project (Eisenhardt, 1995). These hetrogeneous groups stimulate the process of divergent thinking and this diversity in thinking bring about more objective discussions during group meetings that pave the way towards solutions for complex problems. Rotating members across groups bring new knowledge and share it with their co-workers (A Kane, 2005). In fact rotation of group memebers and formation of ad-hoc project based groups and returning of members back to their original groups generate a pool of knowledge across organizations (Lushan Pan, 2010) and sharing of knowledge moderates the context of new knowledge creation. Inter group relationship and multi-tasking, keeping more than one group in a pool, gives opportunity to joint practices within a team working model, where the principles of effective team working are examined as well as the interaction of context, tasks, team roles and processes; only if diverse individuals work together in teams in a context where they can learn from the outcomes of their actions will bring the possibility of successful innovation. (Abbott, 1992; Adler, 1990; Adler P. S., 1993; Addleson, 1996), this interaction not only produces new sphere of knowledge but even ignites communities of understanding that strengthens the Organizational learning process further and farther (Agor, 1996).

Social Networking and informal relationships seem even very helpful and developmental in new knowledge creation within Organization (Hansen, 1996) as in order to maintain a sustainable competititve advantage a firm is in need to produce 
Independent Journal of Management \& Production (IJM\&P) ISSN: 2236-269X DOI: 10.14807/ijmp.v3i2.42

v. 3, n. 2, July - December 2012

innovative applications through combination and recombination of existing knowledge (Kogut, 1992) company's own knowledge generating capabilities bear more fruit than relying on external sources as News letter, training programmes, workshops, videographic presentations, peer-subordinate sessions, knowledge circles etc.

The importance of inerpersonal networks for organizations is the core insight of economic sociology and organization theory. A number of studies show the relevalnce of key network concepts, such as tie strength (Granovetter, 1973), closure (Coleman, 1988) and structural holes (Burt, 1992), to a variety of collective and individual outcomes in organizational contexts, such as promotion and rewards, turnover, learning and knowledge sharing and innovation (Burt, 1992; Hansen 1999; Krackhardt and Porter, 1985; Obstfld, 2005; Podolny and Baron, 1997), and the knowledge transfer is facilitated by the intensive social interaction of organizational actors (Andrew C Inkpen, 2005) and these actors generate new knowledge during the course of their interaction.

In a variety of relevant contexts \{rational working groups or teams and meetings the idea exchange and knowledge sharing becomes an prominent aspect of group interaction (Antoszkiewicz, 1992; Galegher, 1990) while the brainstorming session in groups pave the way for generating new ideas as compared to isolated brain storming (Mullen, 1991), another study by Paulus and Young suggested that brainstorming sessions accelaerate the idea exchange process within a group and these sessions are the fundamental means to bring creativity and innovation in an organization, (Yang, 2000). The opportunity of interaction not only generates new knowledge but refine and reform the existing knowledge as experience sharing sessions excells the participants/group members to share in the light of empirical evidence and the core basis for these empirical evidence is experience.

In this very connection the Man-tool basis task in an organizationn generates new spheres of knowledge as in Business Process Re-Engineering $\{B P R\}$, the core focus is technological automation and when the technology is automated and new technology is brought in then organizational memebers who used to produce the same product with obsolete technology try to find a link between the old and new technology and this link justifies the changes which they find from old to new, they even generate 
Independent Journal of Management \& Production (IJM\&P) ISSN: 2236-269X DOI: 10.14807/ijmp.v3i2.42

v. 3, n. 2, July - December 2012

new knowledge as the focal point of bringing new thechnology is by far bringnging new knowledge and mechanism in an organization (Carr, 2003)

In short, it can be said that past and recent studies emphasized the people phenomena in knowledge creation and significantly emphasize over the intraorgsanizaitonal social networkig, groups, teams and people gathering as the prime source of bringing in novel ideas and new knowledge in an organization. Human being are considered as the source which not only generates knowledge but even exemplifies the usage and reformation upto desired and demanded extent.

\section{Problems and Significant Factors affecting knowledge CREATION process}

1. Environemtal and Organizational context in which knowledge creation takes place, is needed to be taken into account in order to develop a holistic framework for knowledge creation (Christine W. Soo, 2002)

2. Provision of resources required for problem solving as knowledge fundamentals, knowledge networks values and functional/operational systems (Jaana Woiceshyn, 2008)

3. Principal role of organizational hierarchy and the concerned problem relevant to organizational routines and practices (Raybaut, 2004)

4. Limitations in knowledge creation hampers the flow of sustainable advantage (Bhatt, 2000)

\section{Knowledge Codification}

In fact, codification of knowledge can reduce the costs of knowledge acquisition. In its true sense, codification reduces the costs and improves the reliability of information storage and recall and through codification; knowledge is becoming more like a commodity that paves the way for knowledge description in the very right perspective of objective contents and intellectual property and eventually it leads to economize the cost of knowledge acquisition (Simon, 1982). The due steps in codification are encircled within the fold of applied technology in order to not only gain the process economization but even hold the time frame at fast track. Devenport and Prusak consider codification as a process with the help of which knowledge becomes 
Independent Journal of Management \& Production (IJM\&P) ISSN: 2236-269X DOI: 10.14807/ijmp.v3i2.42

v. 3, n. 2, July - December 2012

portable, re-usable and trnasferable,(Davenport T. H., 1998). Unfortunately, the step of knowledge codification has not had been very well described, understood and naratted in knowledge management studies. There is therefore a need to explore and understand better the process of knowledge codification as a vehicle for affecting the transfer of knowledge with in organization. While applying the term codification to knowledge, conversely, KM reviewers such as Davenport and Prusak (1998) and Ruggles (1997) give the impression to shine over the social dimensions to knowledge codification which trail from the generation, usage and elucidation of the codes required to communicate knowledge. Furthermore, the collected works on communities of practice proposes that alike knowledge bases and "shared histories of learning" (Wenger, 1998) tie practitioners in informal relationships which, according to Wenger and Snyder (2000), are the model platform for sharing and disseminating finest practices across the organization.

The role of information and communication technologies cannot be undermined or overlooked when we discuss them in knowledge codification and by every passing day the due importance is touching new heights, the same has had been the core topic of different Research studies (Boland Jr. and Tenkasi, 1995; Alavi, 1999; Scarbrough et al., 1999; Swan et al., 1999a; Robertson et al., 2000). Information technology facilitates the process of development of non-human repositories, while intra-group communication is most significant a tool to establish human repositories in an organization.

The core of knowledge codification is to convert this codified knowledge into application which is the intrinsic function of the whole process to gain competititve advantage and this externalization of knowledge is needed for sharing (Choo, 1998) among groups within organizations, due to the inherent nature of continuous refinement in $\mathrm{KM}$, transformations are never constant. Thus the ratio of input and output in every phase of knowledge transformation is inelastic and non-linear (Datta, 2010) and continuously in need of revision, amendments and changes. Inter-group relationship with reference to knowledge exchange is very strong and creative as every group comes across a new set of knowledge and their day to day interaction provides them 
Independent Journal of Management \& Production (IJM\&P) ISSN: 2236-269X DOI: 10.14807/ijmp.v3i2.42

v. 3, n. 2, July - December 2012

ample chances to share with one another and put the new knowledge into practice and use knowledge to solve critical and complex problems (Cassi, 2007) and carry the same forward as a continuous process.

\section{Problems and Significant Factors affecting knowledge CODIFICATION process}

1. Cost-benefit analysis of codification with respect to tacit and explicit knowledge as tacit knowledge is difficult to be codified in its true and applied sense. (Robin Cowan, 2000)

2. Compatibility of codification with intra organizational knowledge tranfer, innovation, classification and communication (Lundh-Snis, 2010)

3. Maintain Standardization in tacit experiences and explicit procedural knowledge (Zollo, 1998)

4. Studying and keep in mind the role of practicing communities of workers who are keen about the difference between tacit and codified explicit knowledge. (B. Ancori, 2000)

\section{Knowledge Retention}

The fundamental issue in Knowledge retention is to get down to the repositories where knowledge is embeded (Levitt, 1988), organizational members' insight and experiences generate knowledge, Such insights and experiences either exemplified in individuals or implanted in organizations as processes or practices. The process of knowledge codification and dissemination is dependent upon knowledge retention or 'knowledge categorization' as the intra-organizational learning seems reliant on features of individual memory (Hastie, 1984; Johnson, 1987) when member-member \& membertask [functional] tasks are derived, same as in member-tool-task [operational] relationship.

We need to look into the core division of an organization in order to understand the intrinsic knowledge repositories that not only keep organizational knowledge but are the core sources for organizational learning. Intra-organizational linkages are formed through these sources when we discuss Business Process Re-Engineering (BPR) and Business Process Improvement (BPI). 
Independent Journal of Management \& Production (IJM\&P) ISSN: 2236-269X DOI: 10.14807/ijmp.v3i2.42

v. 3, n. 2, July - December 2012

Every organization is a combination of certain functional and operational departments, services based organizations [consultants, lawyers, Training] are dominantly functional organizations where operational departments provide back up to functional departments on the other hand Manufacturing Organizations [Construction, product based manufacturing etc.] incorporate the complex operational processes to generate output and functional departments in these organizations are providing back up to the core operational departments. Manufacturing organizations are based upon operations which derive member-tool-task relationship and the Knowledge repositories are most of the time are non-human and flow of knowledge in the organization is limited to the sphere of technology in-use and the process of knowledge creation, codification is linked with the Business Process Re-Engineering \{technological automation\} while the Service based organizations are functional and their knowledge repositories are human and the process of knowledge creation and codification seems linked with members' knowledge and they work upon Business Process Improvement. We further strengthen our standpoint with reference to knowledge areas and types in these organizations that would exemplify the repositories of knowledge in these organizations as:

Table 1: Comparison of Manufacturing \& Service Organizations

\begin{tabular}{|c|c|c|}
\hline Member-Tool-Task Relationship & $\begin{array}{l}\text { Human Resource } \\
\text { Management }\end{array}$ & Production \\
\hline & Finance and Accounts & Supply Chain Management \\
\hline & Administration & Quality Control \\
\hline & Marketing and Sales & Packing and Packaging \\
\hline & Training and Development & Delivery \\
\hline & Stores & $\begin{array}{l}\text { After Sales Technical } \\
\text { support }\end{array}$ \\
\hline & Customer Services & Trouble Shooting \\
\hline & Documentation & Data Base Management \\
\hline & & Maintenance \\
\hline Service Organization & $\begin{array}{l}\text { Human Resource } \\
\text { Management }\end{array}$ & Data Base Management \\
\hline \multirow[t]{6}{*}{$\begin{array}{l}\text { Member-Task, Member-Member } \\
\text { Relationship }\end{array}$} & Finance and Accounts & Maintenance \\
\hline & Administration & \\
\hline & Marketing and Sales & \\
\hline & Training and Development & \\
\hline & Customer Services & \\
\hline & Documentation & \\
\hline
\end{tabular}


Independent Journal of Management \& Production (IJM\&P) ISSN: 2236-269X DOI: 10.14807/ijmp.v3i2.42

v. 3, n. 2, July - December 2012

Table 2: Organization \& Knowledge Type

\begin{tabular}{|l|l|}
\hline Organization Type & Organization Type \\
\hline Manufacturing & Services \\
\hline Knowledge Area & Knowledge Area \\
\hline Production/Manufacturing & Training \& Development \\
\hline Knowledge Type & Knowledge Type \\
\hline Machines & Training Trends \\
\hline Process of Production & New Courses Development \\
\hline Trouble Shooting & Consumer Behavior \\
\hline Safety Procedures & Customer Relationship \\
\hline Floor Lay out & Impression Management \\
\hline Raw Materials & Personal Effectiveness \\
\hline Time and Motion Framework & Self Academic Up-gradation \\
\hline Job Description & \multicolumn{1}{|l}{} \\
\cline { 2 - 2 } &
\end{tabular}

It would be a challenging task to define and measure knowledge, especially at intra-organizational level of analysis as (Hargadon, 2002) most of the time, Researchers focus upon the cognitions of organizational members (McGrath, 2001; Huff, 2002) to ascertain organizational knowledge. According to the framework of McGrath and Argote, (Argote L., 1993) knowledge is embedded in the three basic elements of organizations-members, tools, and tasks-and the various sub-networks formed by combining or crossing the basic elements. As described earlier that human repositories are the most significant one that not only store knowledge but by the passage of time revise it and incorporate it with required and due changes and amendments. Intellectual capital (IC), the knowledge assets, has become one of the most-sought after business management subjects; it correspondingly regulates success or failure of modern enterprises. Furthermore, many researchers regard intellectual capital as an asset that generates a company's modest advantage and productive value (Dong et al, 2010). It must be kept in mind that knowledge retention is fundamentally focusing upon those specific areas of knowledge that is at risk of departure and loss (Holsapple, 2002; Snyder, 2000; Snyder C. \&., 1998) and the core of intra-organizational learning is to have this knowledge codified pro-actively before it is wasted or hand washed. Floating knowledge repositores are even stronger in an organization and members joining new groups and coming back to their mother groups leaves a knowledge gap and this gap is to be filled through continuous knowledge upgradation keeping corresponding memebers on board. 
Independent Journal of Management \& Production (IJM\&P) ISSN: 2236-269X DOI: 10.14807/ijmp.v3i2.42

v. 3, n. 2, July - December 2012

\section{Problems and Significant Factors affecting knowledge RETENTION process}

1. Organization's structures and working systems are necessary to be taken into close consideration as these two vary from organization to organization (Lam, 1997)

2. Implications on Human Resource Management practices to knowledge transfer and expertise retention in case of tacit knowledge (Fish, 2000)

3. The flow of human capital and organization's physical expansion and amount of new knowledge production (Madsen, 2002)

4. Develop a clear relation, balance and harmony among knowledge based resources, activities and return on investment (ROI) (McManus, 2003)

\section{Knowledge Transfer}

Movement of members between groups is a fundamental way of intraorganizational knowledge transfer (Rothwell, 1978; Allen, 1977), studies show that sub units posses implicit (specialized) knowledge and their interaction provides ample opportunity in transfering this knowledge from one unit to another (Huber, 1991), interunit link and network enables unites to learn from one another and paves the way towards accessing required knowledge (Hansen M. T., 1999) as this networking establishes a shared social context which links different units to one another (Gresov, 1993) and their linkage dilutes the self-centric perception and reduces the notion of individuality and swift knowledge transfer starts taking place that leads to organizational learning and this learning network difuses the hindrane of conventional hierarchicahl structure.

All the organizational units are interlinked with one another being the part of an organization but their active part, place and prminance in overall processing captiones their abilities to acquire and absorb new knowledge, rather acquire new knowledge from external sources and transfer it accordingly to other units (Tsai, 2001), this units enjoys central position and due to its central positioning it emits and absorb knowledge at the same time. 
Independent Journal of Management \& Production (IJM\&P) ISSN: 2236-269X

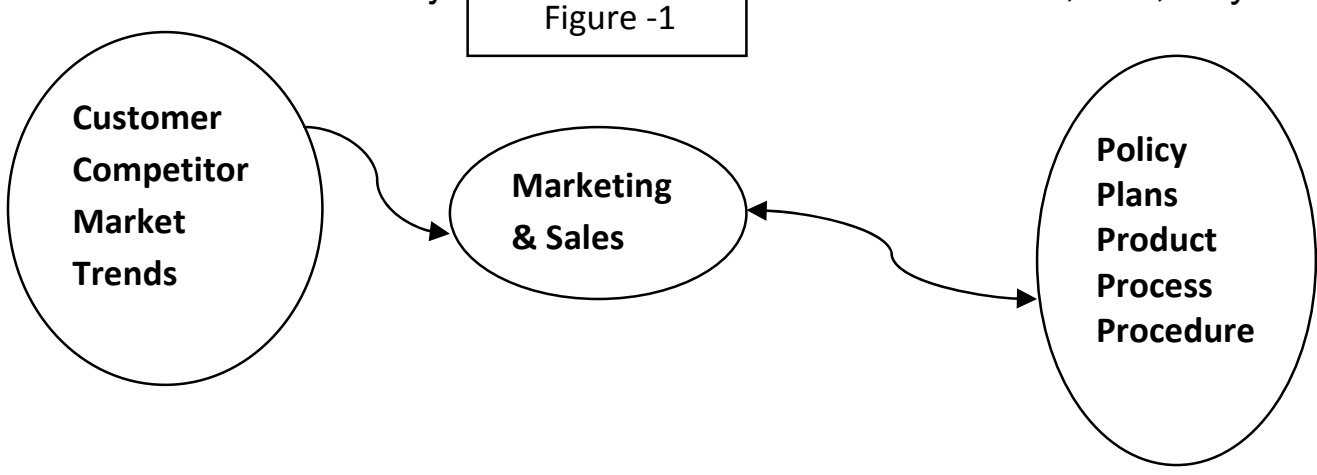

v. 3, n. 2, July - December 2012

This positioning often creates an imbalance in the process of knowledge transfer as the central unit needs specific resources for gaining external knowledge and innovativeness but this new knowledge cannot be disseminated to other units if proper relationship is not there and unevenness of different units hamper the desired level needed to accept new knowledge (Szulanski, 1996). It is for sure that central unit(s) in an organization bring(s) innvoation, new knowledge and ideas into organization and become(s) starmark for other units; since that, because of their unique positioning, there are ample chances to come across new knowledge areas and by developing a socialized network intra-organizaitonal knowledge ransfer can generate more economic value and strengths (Coleman J. S., 1990) on lasting basis.

The corresponding relationship among groups appear in two different facets as routine-task relationship and project-task relationship; in routine-task relationship, the intra-organizational social networking is beneficial as it allows memebers to share and transfer knowledge easily to one another on individual and group basis (Leavitt, 1951) but, on the other hand the project-task relationship seems intense and rapid and opens an opportunity for involved group memebers towards innovation and new knowledge generation while this knowledge transfer canot take place in a centralized manner, as this knowledge is experiential in nature and every involved member passes through certain process, right from the project commencement till termination and this knowledge transfer process takes place in a de-centralized manner as specialized knowledge is the matter of concern here (Heise, 1951), organization and network level qualifications differentially impact organizational knowledge transfer (Raymond Van Wijk, 2008) and member-member communication is more concerned in this case (Andreas Schotter, 2009). 
Independent Journal of Management \& Production (IJM\&P) ISSN: 2236-269X DOI: 10.14807/ijmp.v3i2.42

v. 3, n. 2, July - December 2012

Collective capability of an organization has been emphasized so much so far, but, the notion of individuality is even a matter or related concern as discussed above, the core reason is that when we talk of implicit knowledge then collectivism has no place here and specialized knowledge rests always within an individual, that is why intra-organizational knowledge transfer needs to give attention to individuals (Grant, 1996), individual uniformity (Felin, 2007) and individual behavior (Gupta, 1991), in another study it was focussed that individual motivation, capability and opportunity are the key considerable factors (Argote , 2003) in intra-organizational knowledge transfer process and in the case of implicit knowledge it is something must be comprehended at the first place. In addition to it, the prioir experience and gained knowledge also affects the knowledge transfer process when we talk of individual; the experience gained in a task generates new knowledge (Cohen, 1990) and this knowledge helps individual in preforming same or similar task with more efficeincy and precision as it relates basically to member-task relationship.

As discussed earlier similarity in units helps the knowledge trasfer process (Darr, 2000) within an organization, as compared to diss-similar groups as both the group memebers passes through certain or same experiences in different context and conditions and this similarity of repeated experience enables them to learn form one another experiences.

\section{Problems and Significant Factors affecting knowledge TRANSFER process}

1. Absorptive capacity of a unit and network positioning is needed to be considered as both of these are prone to change sharply (Tsai, 2001)

2. Motivation, its kinds and inter/intra group effects in order to establish a streamline flow of knowledge across organization (Frey, 2000)

3. Individual, Intrapersonal, social barriers, organizational politics and hierarchical interfaces based upon changing humana behaviour (Disterer, 2001)

\section{Conclusion}

Intra-Organizational knowledge management has become a subject of sheer importance and increasing competitiveness, operating cost issues, mergers, 
Independent Journal of Management \& Production (IJM\&P) ISSN: 2236-269X DOI: 10.14807/ijmp.v3i2.42

v. 3, n. 2, July - December 2012

uncertainities, emerging risk factors have made it even more core, central and significant. The commodity of kings in this $21^{\text {st }}$ century is not land, capital or assets but knowledge and the fast track progress pace can only be ascertained if knowledge generation, codification, retention and transfer is undertaken in a very well knitted, documented and systematized manner.

\section{Existing issues and questions}

Knowledge is recognized as an initial and critical source of power that derives an organization and appears rare in the general working envronment (Hackney, 2005) so should the process of knowledge transfer be kept secret (Desouza, 2005) from shareholders, all employees etc., it difuses the level of optimism in knowledge generation and trnasfer process.

A sense of competition among different sub units has become a major challenge in managing intra-organizational knowledge and its trasnfer (Kogut B. a., 1993), especially when a large organization possesses sub units in different locations with unique strategic distinctiveness and roles.

For the better utility and usage of knowledge (Drucker P. , 1993), the process of categorization of knowledge is extremely important in order to understand the capability and operationalization of it, while most of the companies are not functionaly categorizing knowledge and it derails the codification process at intra-organizational knowledge manageemnt level.

The process of extracting knowledge from the knowledge workers (Kreiner, 2002) is indipensible when we discuss tacit knowledge but the documented system of collecting this knowledge is in its very initial phases that pictures the knowledge loss.

\section{Refrences}

A KANE, L. A. (2005). Knowledge transfer between groups via personnel rotation: Effects of social identity and knowledge quality. Organizational Behavior and Human Decision Processes Volume: 96, Issue: 1, 56-71.

ABBOTT, J. a. (1992). Assessing the Appropriateness of Self-Managed Learning. Journal of Management Development, Vol. 11, no. 1, 50-60. 
Independent Journal of Management \& Production (IJM\&P) ISSN: 2236-269X DOI: 10.14807/ijmp.v3i2.42

v. 3, n. 2, July - December 2012

ADDLESON, M. (1996). Resolving the spirit and substance of organizational learning. Special issue of Journal of Organizational Change Management .

ADLER, P. S. (1990). Shared learning. Management Science, Vol 36, No. 8, 938-57.

ADLER, P. S. (1993). Designed for Learning: A tale of two auto plants. Sloan Management Review, Spring, 85-94.

AGOR, H. (1996). Brain skill management. Review of Public Personnel Administration, Vol. 16, No. 3, 14-22.

ALAVI, M. (1999). Knowledge Management and KNowledge Management Systems. Journal of AIS, vol 1, no. 1.

ALLEN, T. J. (1977). Managing the Flow of Technology: Technology Transfer and The Dissemination of Technological witin $R \& D$ Organizations. Cambridge, MA: MIT Press.

ANDERSON, N., ONES, D., \& SINANGIL, H. \&. (2002). Personnel psychology. In Handbook of industrial, work and organizational psychology, Volume 1. Thousand Oaks, CA: Sage Publications Ltd.

ANDREAS SCHOTTER, N. B. (2009). Intra-organizational knowledge exchange: An examination of reverse capability transfer in multinational corporations. Journal of Intellectual Capital Volume: 10, Issue: 1, 149-164.

ANDREW, C., INKPEN, E. W. (2005). Social capital, networks, and knowledge transfer. Academy of Management Review Volume: 30, Issue: 1, 146-165.

ANTOSZKIEWICZ, J. D. (1992). Brainstorming-Experiences from two thousand teams. Organization Development Journal, , 33-38.

ARGOTE, L. \&. (1993). Group processes in organizations: Continuity and change. International Review of Industrial and Organizational Psychology, 8, , 333-389.

ARGOTE, L. \&. (2000). Repositories of knowledge about productivity and timeliness in franchise organizations:Individual structure and technological, in G Dosi, R.Nelson \& S. Winter (eds), Nature and Dynamics of Organizational Capabilities. Oxford: Oxford Univesity press.

ARGOTE, L. B. (2003). Introduction to the special issue on managing knowledge in organizations: Creating, retaining, and transferring knowledge. Management Sci. 49(4), v-viii.

ARGYRIS, C. \&. (1978). Organizational Learning. Reading, MA: Addison-Wesley. 
Independent Journal of Management \& Production (IJM\&P) ISSN: 2236-269X DOI: 10.14807/ijmp.v3i2.42

v. 3, n. 2, July - December 2012

ARGYRIS, C. a. (1996). Organisational learning II: Theory, method and practice.

Reading, Mass: Addison Wesley.

ARMSTRONG, M. (2000). The name has changed but has the game remained the same? Employee Relations, Vol. 22 No. 6, , 576-89.

ASHBY, W. (1956). An Introduction to Cybernetics. Part Two: Variety. London: Methuen.

B. ANCORI, A. B. (2000). The economics of knowledge: the debate about codification and tacit knowledge. Cambridge Journal of Economics 9 (2), 255-287.

B. ANCORI, A. B. (2000). The economics of knowledge: the debate about codification and tacit knowledge. Cambridge Journal of Economics 9 (2), 255-287.

BACDAYAN, M. D. (1994). Organizational Routines Are Stored as Procedural Memory: Evidence from a Laboratory Study. Organization Science1994 vol. 5 no. 4.

BARROWS, H. (1988). The Tutorial Process. Springfield, Illinois: Southern Illinois University Press.

BERRY, D. \&. (1984). On the relatiojship between task performance and associated verbalizable knowledge. The Quarterly Journal of Experimental Psychology (36 A), 209-31.

BHTT, G. D. (2000). Information dynamics, learning and knowledge creation in organizations. The Learning Organisation: vol 1 issue 2, 89-99.

BOLAND Jr., R. J. (1995). Perspective Making and Perspective Taking in Communities of Knowing. Organization Science, vol. 6, no. 4, 350-372.

BURT, R. S. (1992). Structural Holes: The Social Structure of Competition. Cambridge: Harvard University Press.

CAGAN, J. \&. (2002). Creating breakthrough products: Innovation from product planning to program approval. Upper Saddle River, NJ: Prentice Hall.

CAMPBELL, J. P. (1990). Modeling the performance prediction problem in industrial and organizational psychology. In Handbook of Industrial and Organizational Psychology (pp. 687-732). Palo Alto, CA: Consulting Psychologists Press, Inc.

CARR, N. (2003). IT doesn't matter. Harvard Business Review, Vol. 81 No. 5, 41-9.

CASSI, S. B. (2007). Re-Inventing the Wheel: Knowledge Integration in Fast-changing Environments. KITeS Working Papers 209, Universita' Bocconi, Milano, Italy. 
Independent Journal of Management \& Production (IJM\&P) ISSN: 2236-269X DOI: 10.14807/ijmp.v3i2.42

v. 3, n. 2, July - December 2012

CHOO, C. W. (1998). The Knowing Organization: How Organizations Use Information to Construct Meaning, Create Knowledge, and Make Decisions. New York: Oxford University Press.

CHRISTINE, W., SOO, D. M. (2002). The Process of Knowledge Creation in Organizations. SSRN: http://ssrn.com/abstract=376080 or http://dx.doi.org/10.2139/ssrn.376080.

COHEN, W. D. (1990). Absorptive capacity: A new perspective on learning and innovation. Administrative Sciences Quarterly 35, 128-152.

COLEMAN, J. (1988). Social Capital in Creation of Human Capital. The American Journal of Sociology 94, 95-120.

COLEMAN, J. S. (1990). Foundations of social theory. Cambridge, MA: Harvard University Press.

COOK, S. \&. (1999). Bridging Epistemologies: The Generative Dance between Organizational Knowledge and Organizational Knowing. Organization Science, (10:4), 381-400.

COX, T. L. (1991). Effects of ethnic group cultural differences on cooperative and competitive behavior on a group task. Academy of Management Journal, 34, 827-847.

DANIEL HENNEKE, C. L. (2007). Interdisciplinary Heterogeneity as a Catalyst for Product Innovativeness of Entrepreneurial Teams. Creativity and Innovation Management Vol: 16, Issue: 2, 121-132.

DARR, E. D. (2000). An investigation of dimensions of knowledge Transfer. Organizational Behavior and Human Decision Processes (82), 28-44.

DATTA, P. (2010). From Knowledge Codification To Application: An Agent Perspective. Journal of Knowledge Management Practice, Vol. 11, No. 4.

DAVENPORT, T. H. (1998). Working knowledge: How organizations manage what they know. . Boston, Mass: Harvard Business School Press.

DAVENPORT, T. P. (1998). Working Knowledge: How Organizations Manage What They Know. Cambridge, MA: Harvard Business School Press.

DENISE, J., MCMANUS, L. T. (2003). Assessing the Business Value of knowledge retention projects: Result of four case studies. Wake Forest University Publications, 1-7. 
Independent Journal of Management \& Production (IJM\&P) ISSN: 2236-269X DOI: 10.14807/ijmp.v3i2.42

v. 3, n. 2, July - December 2012

DESOUZA, K. a. (2005). Securing knowledge in organizations: lessons from the defence and intelligence sectors. International Journal of Information Management 25(1), 85-98.

DISTERER, G. (2001). Individual and social barriers to knowledge transfer. Proceedings of the 34th Annual Hawaii International Conference.

DODGSON, M. (1991). Technology, learning, technology strategy and competitive pressures. British Journal of Management, 2/3, 132-149.

DRUCKER, P. (1993). The Ecological Vision: Reflections on the American Condition. New Brunswick, NJ: Rutgers University Press.

DRUCKER, P. (2002). The Effective Executive. New York.: Harper Business.

E. RULLANI, B. D. (1990). Management e le Macchine. Mulino.

EASTERBY-SMITH, M. B. (1999). Organizational Learning and the Learning Organization. London: Sage Publications.

EISENHARDT, K. M. (1995). Accelerating adaptive processes: product innovation in the global computer industry. Administrative Science Quarterly , 40, 84-110.

EVENSEN, D. A. (2000). Problem-Based Learning: A Research Perspective on Learning Interactions. New Jersey: Lawrence Erlbaum Associates.

FAHEY, L. A. (1998). The eleven deadliest sins of knowledge management. California Management Review 40(3):, 265-276.

FELIN, T. W. (2007). The knowledge-based view, nested heterogeneity, and new value creation:Philosophical considerations on the locus of knowledge. Acad. of Management Rev. 32(1), 195-218.

FIOL, C. \&. (1985). Organizational Learning. Acadamy of Management Review, 10:4, 803-813.

FISH, S. B. (2000). The transfer of knowledge and the retention of expertise: the continuing need for global assignments. Journal of Knowledge Management Vol. 4 Iss: 2, $125-137$.

FREY, M. O. (2000). Motivation, Knowledge Transfer and Organizational forms. Organization Science: vol 11, issue 5, 538-550.

GALEGHER, J. K. (1990). Intellectual teamwork: Social and technologica Ibases for cooperative work. Hillsdale, $\mathrm{NJ}$ : Erlbaum. 
Independent Journal of Management \& Production (IJM\&P) ISSN: 2236-269X DOI: 10.14807/ijmp.v3i2.42

v. 3, n. 2, July - December 2012

GRANT, R. (1996). Grant, R. 1996. Toward a knowledge-based theory of the firm.

Strategic Management J. 17 109-122. Strategic Management J. 17 , 109-122.

GRENOVETTER, M. (1973). The Strength of weak Ties. The American Journal of Sociology 78(6), 1360-1380.

GRESOV, C. \&. (1993). The context of interunit influence attempts. Administrative Science Quarterly 38, 252-276.

GUPTA, A. A. (1991). Knowledge Flows and the Structure of Control within Multinational Corporations. Academy of Management Review, 18(4), 768-792.

HACKNEY, R. D. (2005). Cooperation or competition: Knowledge sharing processes in interorganisational networks. In Second international conference on knowledge management. Charlotte, North Carolina.

HAMBRICK DC, C. S.-J. (1996). The influence of TMT heterogeneity on firm's competitive moves. Administrative Sciences Quarterly 41, 659-684.

HANSEN, M. (1996). Knowledge Integration in Organizations. Ph.D.

Dissertation, Graduate School of Business, Stanford University, 2.

HANSEN, M. T. (1999). The search-transfer problem: The role of weak ties in sharing knowledge across organizational subunits. Administrative Science Quarterly 44, 82-111.

HARGADON, A. F. (2002). Action and possibility: Reconciling duel perspectives of knowledge in organizations. Organ. Science. 13(3), 290-300.

HARTNESS, J. (1912). The Human Factor in Works Management. New York and London: McGraw-Hill.

HASTIE, R. P. (1984). Social Memory. In Handbook of Social Cognition (pp. 151-212). Hillsdale, NJ: Erlbaum.

HEISE, G. A. (1951). Problem-solving by small groups using various communications nets. Journal of Abnormal and Social Psychology, (46), 327-351.

HOLSAPPLE, C. A. (2002). Knowledge Management: A Three-Fold Framework.

HUBER, G. P. (1991). Organizational learning: The contributing Processes and the Literature. Organization Science: 2, 88-125.

HUFF, A. S. (2002). Mapping strategic knowledge. Thousand Oaks, CA: Sage Publications. 
Independent Journal of Management \& Production (IJM\&P) ISSN: 2236-269X DOI: 10.14807/ijmp.v3i2.42

v. 3, n. 2, July - December 2012

ITIN, C. M. (1999). Reasserting the Philosophy of Experiential Education as a Vehicle for Change in the 21st Century. The Journal of Experiential Education:22(2), 9198.

JAANA WOICESHYN, L. F. (2008). Value creation in knowledge-based firms: Aligning problems and resources. Academy Of Management Perspectives Volume: 22, Issue: 2, 85-99.

JACKSON, K. A. (1989). Top management and innovations in banking: Does the composition of the top team make a difference? Strategic Management Journal Volume 10, Issue S1, 107-124.

JEHN, K. N. (1999). Why differences make a difference: A field study of diversity, conflict, and performance in work groups. Administrative Science Quarterly, 44, 741-763.

JOHNSON, M. H. (1987). Human Learning and Memory. Psycholoy (Annual review): $38,631-68$.

KIRCHMEYER, C. \&. (1992). Multicultural groups: Their performance and reactions with construcitve conflicts. Group \& Organization Management, 17, 153-170.

KOGUT, B. \&. (1992). Knowledge of the firm, combinative capabilities and the replication of technology. Organization Science, 3, 3, 383-397.

KOGUT, B. a. (1993). Knowledge of the firm and the evolutionary theory of the multinational corporation. Journal of International Business Studies, 34(6),, 516529.

KOPPES, L. (2007). Historical perspectives in industrial and organizational psychology. Mahwah, NJ: Lawrence Erlbaum.

KOZLOWSKI, S. \&. (2003). Work groups and teams in organizations. In Handbook of Psychology (12) (pp. 333-75).

KREINER, K. (2002). Tacit knowledge management: the role of Artifacts. Journal ofKnowledge Management, 6(2), 112 - 123.

KRISTINA B. DAHLIN, L. R. (2005). Team diversity and information use. 3.

LAM, A. ( 1997). Embedded Firms, Embedded Knowledge: Problems of Collaboration and Knowledge Transfer in Global Cooperative Ventures. Organization Studies vol. 18 no. 6 , 973-996 . 
Independent Journal of Management \& Production (IJM\&P) ISSN: 2236-269X DOI: 10.14807/ijmp.v3i2.42

v. 3, n. 2, July - December 2012

LATHAM, G. \&. (2005). Work motivation theory and research at the dawn of the twentyfirst century. Annual Review of Psychology, 56, 485-516.

LEAVITT, H. J. (1951). Some effects of certain communication patterns on group performance. Journal of Abnormal and Social Psychology, (46), 38-50.

LEONARD, D. S. (1998). The role of tacit knowledge in group innovation. California Management Review, Vol. 40 No.3, 112-32.

LEVITT, B. a. (1988). Organizational learning. Annual Review of Sociology (14), 319-40.

LOCKE, E. \&. (1990). A theory of goal setting and task performance. . Englewood Cliffs, NJ: Prentice-Hall.

LUNDH-SNIS, C. S. (2010). Innovation through knowledge codification. Journal of Information Technology, 83-97.

LUSHAN PAN, Z.-M. W. (2010). Knowledge transfer via personnel mobility: The effect of knowledge about the distribution of information. Social Behavior and Personality Volume: 38, Issue: 10, 1391-1400.

LYNESS, K. \&. (1997). Above the glass ceiling? A comparison of matched samples. Journal of Applied Psychology, 82, 359-375.

MARCH, J. (1991). Explorations and Exploitation in organizational learning. Organization Science 2.

MARY, M., CROSSAN, H. W. (1999). An Organizational Learning Framework: From Intuition to Institution. The Academy of Management Review, Vol. 24, No. 3, 522537.

MCGRATH, R. (2001). Exploratory learning, innovative capacity and managerial oversight. Academy of Management Journal, 44, 118-141.

MIKE PEDLER, J. B. (1991). The Learning Company: a Strategy for Sustainable Developmen. McGraw-Hill.

MILES R. E., S. C. (1986). Organizations: New Concepts for New Forms. California Management Review, 28, 62-73.

MILLIKEN, F. \&. (1996). Searching for common threads: Understanding the multiple effects of diversity in organizational groups. Academy of Management Review, 21, , 402-433.

MITCHELL, T. D. (2003). Motivation:. In Handbook of Psychology, Vol. 12. NewYork. 
Independent Journal of Management \& Production (IJM\&P) ISSN: 2236-269X DOI: 10.14807/ijmp.v3i2.42

v. 3, n. 2, July - December 2012

MOLANI, M. B. (2003). The Richness of Diversity in Knowledge Creation:An

Interdisciplinary Overview. Journal of Universal Computer Science, vol. 9, no. 6.

MULLEN, B. J. (1991). Productivity loss in brainstorming groups: A meta analytic Integration. Basic and Applied Social Psychology, 12, 3-23.

NONAKA I., T. H. (1995). The Knowledge Creating Company. New york: Oxford University Press.

O'CONNOR, M. (2006). A review of factors affecting individual performance in team environments: Theories and implications for library management. Library Management, Vol. 27 Iss: 3, 135 - 143.

OFFERMAN, L. \&. (1990). Organizations of the future: Changes and challenges. American Psychologist, 45, , 95-108.

O'REILLY, C. W. (1997). Group demography and innovation: Does diversity help? Greenwich, CT: JAI Press.

PETTIGREW, A. a. (1991). Managing Change for Competitive Success. Oxford: Basil Blackwell.

PFAU, M. L. (2005). Developing Diversity: Lessons from Top Teams. Strategy+Business Issue 41.

PFEFFER, J. S. (1999). Knowing 'what' to do is not enough: turning knowledge into action. California Management Review, Vol. 42 No.1, 85.

PORTER, K. D. (1985). When Friends Leave: A Structural Analysis of Relationship between turnovers and Stayers' attitude. Administrative Sciences Quarterly 30(2), 242-261.

PRANGE, C. (1999). Organizational learning - desperately seeking theory? London: Sage Publications.

RAYBAUT, N. L. (2004). Knowledge Creation Facing Hierarchy: the Dynamics of groups inside the Firm. Journal of Artificial Societies and Social Simulation vol. 7, no. 2.

RAYMOND VAN WIJK, J. J. (2008). Inter- and Intra-Organizational Knowledge Transfer: A Meta-Analytic Review and Assessment of its Antecedents and Consequences. Journal of Management Studies, Vol. 45, Issue 4, 830-853.

RICHARD CHASE, F. R. (2001). Operations Management for Competitive Advantage,. ISBN 0072506369. 
Independent Journal of Management \& Production (IJM\&P) ISSN: 2236-269X DOI: 10.14807/ijmp.v3i2.42

v. 3, n. 2, July - December 2012

RIORDAN, C. (2001). Relational demography within groups: Past developments, contradictions, and new directions.

ROBERTSON, J. (2008). Uniting people and ideas at Perkins Eastman. Knowledge Management Review, Vol. 10 No.6, 10-13.

ROBIN COWAN, P. A. (2000). The Explicit Economics of Knowledge: Codifcation and Tacitness. Industrial and Corporate Change, 9 (2), 211-253.

ROTHWELL, R. (1978). Some problems of technology transfer into industry: Examples from Textile Machinery Sector. IEEE Transactions on Engineering Management, (EM-25), 15, 20.

RUGGLES, R. (1998). The state of the notion: Knowledge management in practice. California Management Review 40(3):, 80-89.

RUGGLES, R. L. (1997). Tools for knowledge management: An introduction In: R. Ruggles (ed.). Boston: Butterworth-Heinemann.

SALAS, E., \& STAGL, K. \&. (2004). 25 years of team effectiveness in organizations. International Review of Industrial and Organizational Psychology, Vol. 19 , 4791.

SCARBROUGH, H. J. (1999). Knowledge Management: A Literature Review Issues in People Management. Institute of Personnel and Decelopment.

SCHMIDT, F. \&. (1998). The validity and utility of selection methods in personnel psychology. Psychological Bulletin, 124, 262-74.

SENGE, P. (1990). The Fifth Discipline: The Art \& Practice of the Learning Organization. London: Random House.

SENGE, P. (1994). The fifth discipline: The art and practice of the learning organization. New York: Currency Doubleday.

SERRAT, M. O. (2009). Disseminating KNowledge Products. Knowledge Solutions:43.

SIMON, H. (1982). Programs as factors of production", in Models of Bounded Rationality. Behavioral Economics and Business Organization, vol.2.

SNYDER, C. \&. (1998). The process of knowledge harvesting: The key to knowledge management. Business Information Management: Adaptive Futures. 8th Annual BIT Conference, 43 . 
Independent Journal of Management \& Production (IJM\&P) ISSN: 2236-269X DOI: 10.14807/ijmp.v3i2.42

v. 3, n. 2, July - December 2012

SNYDER, C. A. (2000). Corporate memory management: A knowledge management process model. International Journal of Technology Management, Spring.

SOONHEE KIM, H. L. (2010). Factors affecting employee knowledge acquisition and application capabilities. Asia-Pacific Journal of Business Administration, Vol. 2 Iss: 2, $133-152$.

STRINGER, D. J. (2007). 5 Factors That Affect Your Employee's Productivity. National Business Research Institute.

SVEIBY, K. E. (1997). The New Organizational Wealth. Managing \& Measuring Knowledge-Based Assets. San Francisco: Berret-Koehler Publishers Inc.

SWAN, J. S. (1999a). Knowledge management and innovation:networks and networking. Journal of Knowledge Management vol. 3, no. 3,, 262-275.

SZULANSKI, G. (1996). Exploring stickiness: impediments to the transfer of best practice within the firm. Strategic Management Journal 17, 27-43.

T., H. M. (1999). The Search-Transfer Problem: The role of weak ties in Sharing Knowledge across organizaiton subunits. dministrative Sciences Quarterly 44(1), 82-111.

TAMMY L., MADSEN, E. M. (2002). The dynamics of knowledge flows: human capital mobility, knowledge retention and change. Journal of Knowledge Management, Vol. 6 Iss: 2, 164 - 176.

TSAI, W. (2001). Knowledge Transfer in Inraorganizational Networks: Effect of Network Position and Absorptive Capacity on Business Unit Innovation and Performance. Academy of Management Journal vol:44, issue 8, 996-1004.

TSAI, W. (2001). Knowledge Transfer in Intraorganizational Networks: Effects of Network Position and Absorptive Capacity on Business Unit Innovation and Performance. The Academy of Management Journal, Vol. 44, No. 5, 996-1004.

VAN VIANEN, A. \&. (2001). Personality in teams: Its relationship to social cohesion, task cohesion, and team performance. European Journal of Work and Organizational Psychology10(2), 97-120.

BORMAN, W.C., D. I. (2003). Motivation. In Industrial Organizational Psychology, ed. W.C. (pp. 225-54). New York: Wiley.

WENGER, E. (1998). Communities of practice: Learning, meaning and identity. Cambridge: Cambridge University Press. 
Independent Journal of Management \& Production (IJM\&P) ISSN: 2236-269X DOI: 10.14807/ijmp.v3i2.42 v. 3, n. 2, July - December 2012

WENGER, E. C. (2000). Communities of practice: The organizational frontier. Harvard Business Review, 139-145.

WILLIAMS, K. Y. (1998). The complexity of diversity: A review of forty years of Research. Greenwich, CT: JAI.

WILSON, J. M. (1995). An historical perspective on Operations Management. Production and Inventory Management Journal.

YANG, P. B.-C. (2000). Idea Generation in Groups:A Basis for Creativity in Organizations. Organizational Behavior and Human Decision ProcessesVol. 82, No. 1, , 76-87.

ZOLLO, H. S. (1998). The Impact of Knowledge Codification, Experience Trajectories and Integration Strategies on the Performance of Corporate Acquisitions. THE WHARTON FINANCIAL INSTITUTIONS CENTER : working paper series. 